\title{
PENGARUH PENGUNGKAPAN CORPORATE SOCIAL RESPONSIBILITY (CSR) DAN PROFITABILITAS TERHADAP NILAI PERUSAHAAN PADA PERUSAHAAN YANG TERDAFTAR DI IDX30 PERIODE 2012-2016
}

\section{THE EFFECT OF DISCLOSURE OF CORPORATE SOCIAL RESPONSIBILITY AND PROFITABILITY ON COMPANY VALUE IN COMPANIES LISTED IN IDX30 2012-2016}

\author{
Syofria Meidona dan Mely Angraini
}

STIE Sumbar Pariaman

Jl. Kol. H. Anas Malik By Pass Padusunan Kota Pariaman syofriameidona@gmail.com, melyanggraini90@gmail.com

Naskah diterima 22 Mei 2019, di-review 27 Juni 2019, disetujui 29 Juni 2019

\begin{abstract}
The purpose of this study is to determine the influence of corporate social responsibility disclosure and profitability on firm value in the IDX30 from 2012 until 2016. Sampel in this study amounted to 14 companies by using purposive sampling technique. The data analysis method was the multiple regresian analysis using the spss 16 program. The research result in hypothesis testing with a level og significance $5 \%(0,05)$ found that partially corporate social responsibility disclousure hasn't significant influence on the firm value, because a level of significant 0,559 more than 0,05. While profitability has significant influence on the firm value with a significance value 0,000 $<0,05$. Simultaneously corporate social responsibility disclosure and profitability has significant influence on the firm value with a significance value 0,000 $<0,05$. The adjusted $R^{2}$ value of 0,749 means that all independent variables ( corporate social responsibility disclosure and profitability) contribute $74,9 \%$ in explaining the dependent variable (firm value) and the remaining 25,1\% is explained by the outside of this research variable.
\end{abstract}

Keywords: Firm Value, Corporate Social Responsibility Disclosure, Profitability

\begin{abstract}
Abstrak: Penelitian ini bertujuan untuk mengetahui pengaruh pengungkapan corporate social responsibility dan profitabilitas terhadap nilai perusahaan pada perusahaan yang terdaftar dalam IDX30 periode 2012-2016. Sampel dalam penelituan ini berjumlah 14 perusahaan yang diambil dengan menggunakan teknik purposive sampling. Metode analisis yang digunakan adalah regresi linear berganda dengan alat bantu SPSS versi 16 . Hasil penelitian dalam uji hipotesis dengan tingkat signifikan 5\% $(0,05)$ menemukan bahwa secara parsial pengungkapan corporate social responsibility (CSR) tidak berpengaruh signifikan terhadap nilai perusahaan karena tingkat signifikan 0,559 lebih dari 0,05. Sedangkan profitabilitas berpengaruh signifikan terhadap nilai perusahaan dengan nilai signifikan 0,000<0,05. Secara simultan pengungkapan corporate social responsibility dan profitabilitas berpengaruh signifikan terhadap nilai perusahaan dengan signifikansi 0,000<0,05. Nilai adjusted $\mathrm{R}^{2}$ sebesar 0,749 dapat diartikan bahwa pengungkapan corporate social responsibility (CSR) dan profitabilitas berkontribusi sebesar 74,9\% dalam menjelaskan nilai perusahaan dan sisanya sebesar $25,1 \%$ dijelaskan oleh variabel diluar penelitian ini.
\end{abstract}

Kata Kunci: Nilai Perusahaan, Corporate Social Responsibility, Profitabilitas

\section{PENDAHULUAN}

D i era sekarang ini, perusahaan tidak hanya di tuntut untuk terus melakukan inovasi agar perusahaan tersebut bisa terus bertahan dan tumbuh diantara para pesaingnya, bahkan perusahaan harus terus melakukan perbaikan mutu dan kualitas produk yang akan diciptakan. Tapi pada kenyataannya sekarang ini perusahaan 
juga harus turut serta berfikir tentang bagaimana perusahaan tersebut mempunyai nilai yang baik dimata para investor dan masyarakat. Apabila perusahaan sudah mendapatkan penilaian yang baik dari para investor maka perusahana tersebut sudah mencapai tujuannya karena peningkatan nilai perusahaan yang tinggi merupakan tujuan jangka panjang yang seharusnya dicapai oleh perusahaan.

Nilai dari perusahaan dapat juga diartikan sebagaimana orang lain menilai diri kita pribadi. Disaat seseorang menganggap nilai dari diri kita itu mengandung nilai yang positif, maka mereka akan percaya dengan kita. Sama halnya juga dengan perusahaan, Apabila sebuah perusahaan mempunyai citra yang baik dimata publik dan investor maka mereka akan lebih percaya pada perusahaan. Dimana publik akan menunjukkan sifat royal terhadap produk yang kita ciptakan sementara investor akan lebih percaya untuk menanamkan modalnya pada perusahaan.

Nilai perusahaan merupakan suatu kepercayaan atau perspektif yang dibentuk oleh para investor untuk terus berkontribusi bersama dengan perusahaan. Dimana nilai perusahaan akan menentukan apakah investor akan memutuskan untuk melakukan investasi pada suatu perusahaan atau tidak. Maka dari itu nilai perusahaan juga merupakan hal yang penting untuk dijadikan perhatian bagi sebuah perusahaan.

Nilai perusahaan pada dasarnya akan diukur oleh berbagai aspek salah satunya adalah harga pasar saham perusahaan, karena harga saham itulah yang nantinya akan mencerminkan penilaian seorang investor atas keseluruhan ekuitas yang dimiliki (Wahyudi dan Prawestri, 2006 dalam
Permanasari, 2010:3). Semakin tinggi nilai saham maka nilai perusahaan juga akan meningkat karena itu dianggap sebagai tanda sejahteranya pemegang saham didalam perusahaan tersebut. Dimana tujuan suatu perusahaan adalah untuk memaksimumkan kemakmuran pemegang saham dengan memaksimalkan nilai perusahaan (Rubiyani, 2016:23). Hal tersebut membuktikan bahwa nilai perusahan menjadi tolak ukur kesejahteraan pemegang saham didalam suatu perusahaan.

Banyak hal yang akan mempengaruhi nilai perusahaan baik dari berbagai aspek keuangan maupun diluar aspek keuangan. Hal yang dapat dilakukan oleh perusahaan untuk meningkatkan nilai perusahaan yaitu dengan terus melakukan kegiatan - kegiatan sosial serta memperhatikan lingkungan sekitar perusahaan agar terus terjaga yang biasa disebut Corporate Social Responsibility (CSR), dan peningkatkan profit (laba) perusahaan juga dapat meningkatkan nilai perusahaan. Corporate Social Responsibility (CSR) merupakan salah satu langkah yang ditempuh oleh perusahan sebagai usaha untuk dapat meningkatkan nilai perusahaan. Dimana aksi-aksi sosial ini diharapkan dapat membuat publik maupun investor terkesan dan mempunyai perspektif yang baik kepada perusahaan. Karena tidak dapat dipungkiri bahwa publik dan investor tentu akan menunjukkan reaksi kepada perusahaan yang dianggap tidak memperhatikan lingkungan (Agustina, 2013:21). Corporate Sosial Responsibility adalah bentuk tanggung jawab perusahaan dalam memperbaiki kesenjangan sosial serta kerusakan lingkungan yang terjadi akibat aktivitas operasional perusahaan. Semakin banyak bentuk tanggung jawab sosial yang 
dilakukan oleh perusahaan terhadap lingkungan maka nilai perusahaan akan semakin meningkat yang otomatis akan menarik banyak investor untuk menanamkan modalnya kepada perusahaan dan membuat publik akan loyal yang secara langsung akan meningkatkan penjualan dan profitabilitas perusahaan akan meningkat (Retno, 2012:86).

Selain CSR ada juga hal yang akan mempengaruhi nilai perusahaan yang berasal dari aspek keuangan. Salah satunya adalah Rasio Profitabilitas, dimana banyak sekali perusahaan yang berorientasi kepada profit (laba). Karena mereka beranggapan bahwa perusahaan yang memiliki profitabilitas yang tinggi pasti memiliki kinerja yang baik dan menganggap bahwa profit merupakan hasil akhir dari sejumlah kebijakan dan keputusan manajemen (Brigham dan Gapenski, 2006 dalam Nofrita, 2013:5). Para investor akan cendrung melihat suatu perusahaan berdasarkan besar kecilnya profit yang dihasilkan oleh suatu perusahaan. Menurut (Analisa, 2011:43) nilai perusahaan dipengaruhi oleh besar kecilnya profitabilitas yang dihasilkan oleh perusahaan. Karena hal itulah yang nantinya menetukan apakah perusahaan mempunyai prospek yang bagus kedepannya atau tidak, dan tentu juga akan menentukan berapa tingkat pengembalian yang akan diterima oleh investor. Dimana tentu investor akan cendrung menyukai perusahaan yang dapat memberikan return yang besar atas modal yang ditanamkannya dan perusahaan akan lebih mudah dalam manarik modal dari luar perusahaan, sehingga profitabilitas dapat mempengaruhi nilai perusahaan. Profitabilitas adalah kemampuan perusahaan untuk mendapatkan laba selama periode tertentu. Rasio profitabilitas merupakan kemampuan perusahaan mendapatkan laba yang berhubungan dengan penjualan, total aktiva, maupun modal sendiri (Sartono, 2010 dalam Rubiyani, 2016:30).

Tujuan penelitian adalah untuk mengetahui pengaruh pengungkapan corporate social responsibility dan profitabilitas terhadap nilai perusahaan baik secara parsial maupun simultan. Dengan dilakukannya penelitian ini, diharapkan dapat digunakan sebagai review untuk penelitian selanjutnya yang terkait dengan nilai perusahaan, dan dapat memberikan gambaran kepada investor atas keputusan investasinya, mengingat nilai perusahaan suatu perusahaan dipengaruhi oleh berbagai faktor.

\section{METODE PENELITIAN}

\section{Populasi dan Sampel}

Populasi yang digunakan dalam penelitian ini adalah Perusahaan yang terdaftar dalam IDX 30 periode 2012-2016. Teknik pengambilan sampel dalam penelitian ini menggunakan purposive sampling. Purposive sampling merupakan teknik pengambilan sampel dengan kriteria tertentu. Kriteria pengambilan sampel dalam penelitian ini adalah sebagai berikut:

1. Perusahan yang termasuk terdalam IDX 30 berturut - turut selama periode 2012 - 2016.

2. Perusahaan yang menyediakan laporan keuangan berturut - turut selama periode 2012 - 2016

3. Perusahaan yang menyediakan informasi yang dibutuhkan oleh penulis selama penelitian. 
Jumlah sampel yang digunakan dalam penelitian ini sebanyak 14 perusahaan dengan periode pengamatan 5 tahun sehingga jumlah pengamatan penelitian ini adalah sebanyak 70 . Dalam penelitian ini data yang digunakan adalah jenis data sekunder yang bersifat kuantitatif. Data yang diperoleh dari website resmi www.idx.co.id.

\section{Definisi Operasional Variabel}

\section{Variabel Dependen (Terikat)}

Menurut Andri dan Hanung (2007) dalam Retno (2012:90), nilai perusahaan adalah nilai jual perusahaan atau nilai tambah bagi pemegang saham, nilai perusahaan akan tercermin dari harga pasar sahamnya. Nilai perusahaan dapat diukur dengan PBV (price to book value) merupakan rasio pasar yang digunakan untuk mengukur kinerja harga pasar saham terhadap nilai. PBV dapat dirumuskan sabagai berikut:

$$
\mathrm{PBV}=\frac{\mathrm{PS}}{\mathrm{BVS}}
$$

Keterangan:

Ps : Harga saham / Price share

BVS : Nilaibuku perlembarsaham/Book ValueShare

Dimana:

$$
\text { Nilai buku saham }=\frac{\text { Jumlah ekuitas }}{\text { Jumlah saham beredar }}
$$

\section{Variabel Independen (Bebas)}

\section{Pengungkapan CSR (X1)}

Corporate Social Responsibility merupakan bentuk pengungkapan kinerja ekonomi, sosial dan lingkungan yang terdapat pada laporan tahunan perusahaan dengan menggunakan rumus perhitungan Corporate Social Responsibility disclosure berdasarkan GRI (Global Reporting Initiative) (Deriyarso, 2014:89).

$$
\operatorname{CSRDI}=\frac{\mathrm{Xj}}{\mathrm{Nj}}
$$

Keterangan:

CSRDI : Corporate Responsibility disclosure index perusahaan

Xj : Jumlah item yang diungkap oleh perusahaan $\mathrm{j}$

Score 0: Jika perusahaan tidak mengungkapkanitem padadaftarpertanyaan Score 1: Jika perusahaan mengungkapkan item pada daftar pertanyaan.

$\mathrm{Nj} \quad$ : jumlah item pengungkapan oleh perusahaan $\mathrm{j}$

\section{Profitabilitas (X2)}

Menurut Saidi (2004) dalam Deriyarso (2014:32) Profitabilitas adalah kemampuan perusahaan dalam memperoleh laba. Para investor menanamkan saham pada perusahaan adalah untuk mendapatkan return, yang terdiri dari yield dan capital gain. Semakin tinggi kemampuan memperoleh laba, maka semakin besar return yang diharapkan investor, sehingga menjadikan nilai perusahaan menjadi lebih baik.

Dalam penelitian ini profitabilias diukur dengan ROE dimana keberhasilan perusahaan akan terlihat pada nilai ROE. Semakin tinggi rasio ini berarti semakin tinggi laba yang dihasilkan perusahaan. Return on Equity dapat di ukur dengan rumus sebagai berikut (Kasmir, 2018 dalam Mayogi dan Fidiana, 2016:18): 


$$
R O E=\frac{E B I T}{\text { Ekuitas }}
$$

Keterangan :

EBIT : Laba sebelum bunga dan pajak /Earning Before Interest and tax

\section{Metode Analisis Data}

Untuk mengetahui pengaruh pengungkapan corporate social responsibility (CSR) dan profitabilitas terhadap nilai perusahaan menggunakan analisis statistik deskriptif, uji asumsi klasik dan regresi linier berganda dengan alat bantu SPSS V16. Penelitian ini menggunakan analisis regresi linier berganda yang dirumuskan sebagai berikut:

$$
\mathrm{Y}=\mathrm{a}+\mathrm{b} 1 \mathrm{X} 1+\mathrm{b} 2 \mathrm{X} 2+\mathrm{e}
$$

Keterangan:

$$
\begin{array}{ll}
\mathrm{Y} & \text { : Nilai Peusahaan } \\
\mathrm{a} & \text { : Konstanta } \\
\mathrm{X} 1 & \text { : Pengungkapan CSR } \\
\mathrm{X} 2 & \text { : Profitabilitas } \\
\text { B1B2B3 } & : \text { Koefisien Regresi } \\
\text { e } & \text { : Kesalahan Residu }
\end{array}
$$

\begin{tabular}{|c|c|c|c|c|}
\hline & & CSR & PROFITABILITAS & $\begin{array}{l}\text { NILAI } \\
\text { PERUSAHAN }\end{array}$ \\
\hline \multirow[t]{6}{*}{$\mathbf{N}$} & Valid & 70 & 70 & 70 \\
\hline & $M$ is sing & $\mathbf{O}$ & $\mathbf{O}$ & $\mathbf{O}$ \\
\hline & Mean & -3515 & 28744 & 6.67387 \\
\hline & Std. Deviation & $\frac{0716}{23}$ & 309941 & 13.052525 \\
\hline & Minimum & 203 & 089 & 1.054 \\
\hline & Maximum & 481 & 1638 & 62.931 \\
\hline
\end{tabular}

\section{PEMBAHASAN DAN HASIL}

\section{Uji Statistik Deskriptif}

Hasil uji statistik deskriptif dapat kita lihat pada tabel di bawah ini:

Tabel 1 Hasil Uji Statistik Deskriptif Statistics

Sumber : data yang diolah SPSS 16, 2018

Berdasarkan tabel 1 diatas dapat dilihat bahwa jumlah data yang digunakan dalam penelitian ini sebanyak 70 sampel data. Menunjukkan nilai Mean untuk variabel CSR atau Corporate Social Responsibility sebesar 0,351 dengan Standar Deviasi sebesar 0,0716. Untuk nilai minimum sebesar 0,203 nilai tersebut dimiliki oleh perusahaan Bank Central Asia, Tbk pada tahun 2012, sedangkan untuk nilai maksimum diperoleh oleh perusahaan Semen Indonesia, Tbk sebesar 0,481.
Kemudian untuk variabel Profitabilitas nilai Mean menunjukan hasil sebesar 0,287 dengan Standar Devisiasi sebesar 0,309. untuk nilai Minimum sebesar 0,089 dimiliki oleh perusahaan Indofood Sukses Makmur, Tbk pada tahun 2015 dan untuk nilai Maximum dimiliki oleh perusahaan Unilever Indonesia, Tbk.

Sedangkan untuk variabel Nilai perusahaan mendapatkan nilai PBV pada nilai Mean sebesar 6,67 dengan Standar Devisiasi sebesar 13,05 dimana nilai Mean PBV diatas satu menunjukkan 
bahwa perusahaan dalam kondisi baik dimana perusahaan yang memiliki nilai terendah atau minimum dalam penelitian ini adalah perusahaan Indofood Sukses Makmur, Tbk sebesar 1,054 sedangan perusahaan yang memiliki nilai tertinggi atau Maximum dalam penelitian ini adalah perusahaan Unilever Indonesia, Tbk.

\section{Uji Asumsi Klasik}

Hasil uji asumsi klasik dapat kita lihat pada beberapa tabel dengan rincian sebagai berikut:

Tabel 2 Hasil Uji Normalitas

\begin{tabular}{|c|c|c|}
\hline & & $\begin{array}{c}\text { Unstandardized } \\
\text { Residual }\end{array}$ \\
\hline \multicolumn{2}{|l|}{$\mathbf{N}$} & 69 \\
\hline \multirow[t]{2}{*}{ Normal Parameters } & Mean & . OOOOOOOO \\
\hline & Std. Deviation & 2.75620362 \\
\hline \multirow[t]{3}{*}{ Most Extreme Differences } & Absolute & .073 \\
\hline & Positive & 071 \\
\hline & Negative & -.073 \\
\hline \multirow{2}{*}{\multicolumn{2}{|c|}{$\begin{array}{l}\text { Kolmogorov-Smirnov } Z \\
\text { Asymp.Sig. (2-tailed) }\end{array}$}} & .609 \\
\hline & & .853 \\
\hline
\end{tabular}

Sumber : data yang diolah SPSS 16, 2018

Berdasarkan tabel 2 terlihat bahwa data terdistribusi normal serta dapat dilihat bahwa jumlah sampel berkurang dari 70 sampel menjadi 69 sampel. Hal tersebut terjadi karena proses transformasi menggunakan Lag dimana Lag artinya mengembalikan variabel baru yang merupakan hasil pengurangan nilai dari sampel ke-i dikurangi sampel ke i-1. maka dari itu sampel data berkurang dari 70 sampel menjadi 69 sampel data. Setiap uji yang digunakan dalam penelitian ini menggunakan tabulasi data yang sudah ditransformasi. Dari tabel 4.4 tersebut dapat dilihat bahwa nilai kolmogorov-smirnov lebih besar dari nilai signifikan yaitu diatas 0,05 yang berarti data terdistribusi normal.

Tabel 3 Uji Multikolinieritas

\begin{tabular}{|c|c|c|c|c|c|c|c|c|}
\hline \multirow{2}{*}{\multicolumn{2}{|c|}{ Model }} & \multicolumn{2}{|c|}{ Unstandardized Coefficients } & \multirow{2}{*}{\begin{tabular}{|c|}
$\begin{array}{c}\text { Standa } \\
\text { rdized } \\
\text { Coeffici } \\
\text { ents }\end{array}$ \\
Beta \\
\end{tabular}} & \multirow[b]{2}{*}{$\mathrm{t}$} & \multirow[b]{2}{*}{ Sig. } & \multicolumn{2}{|c|}{$\begin{array}{c}\text { Collinearity } \\
\text { Statistics }\end{array}$} \\
\hline & & $\mathrm{B}$ & Std. Error & & & & Tolerance & VIF \\
\hline 1 & $\begin{array}{l}\text { (Constant } \\
\text { ) }\end{array}$ & -6.555 & 4.105 & & -1.597 & .115 & & \\
\hline & CSR & 6.526 & 11.108 & .036 & .587 & .559 & .997 & 1.003 \\
\hline & LAG_X2 & 40.373 & 2.822 & .871 & 14.308 & .000 & 997 & 1.003 \\
\hline
\end{tabular}

a. Dependent Variable: NILAI PERUSAHAAN

Sumber: Hasil Pengolahan SPSS 
Berdasarkan tabel 3 diatas dapat disimpulkan bahwa nilai tolerance untuk variabel CSR 0,997 dengan nilai VIF sebesar 1,003 dan untuk variabel Profitabilitas nilai tolerance sebesar 0,997 dengan nilai VIFsebesar 1,003. dimana hal tersebut dapat diartikan bahwa tidak terdapat gejala multikolinieritas karana masing-masing variabel bebas tersebut mempunya nilai tolerance sebesar 0,997 > 0,10 dan nilai VIF sebesar 1,003 $<10$.

Scatterplot

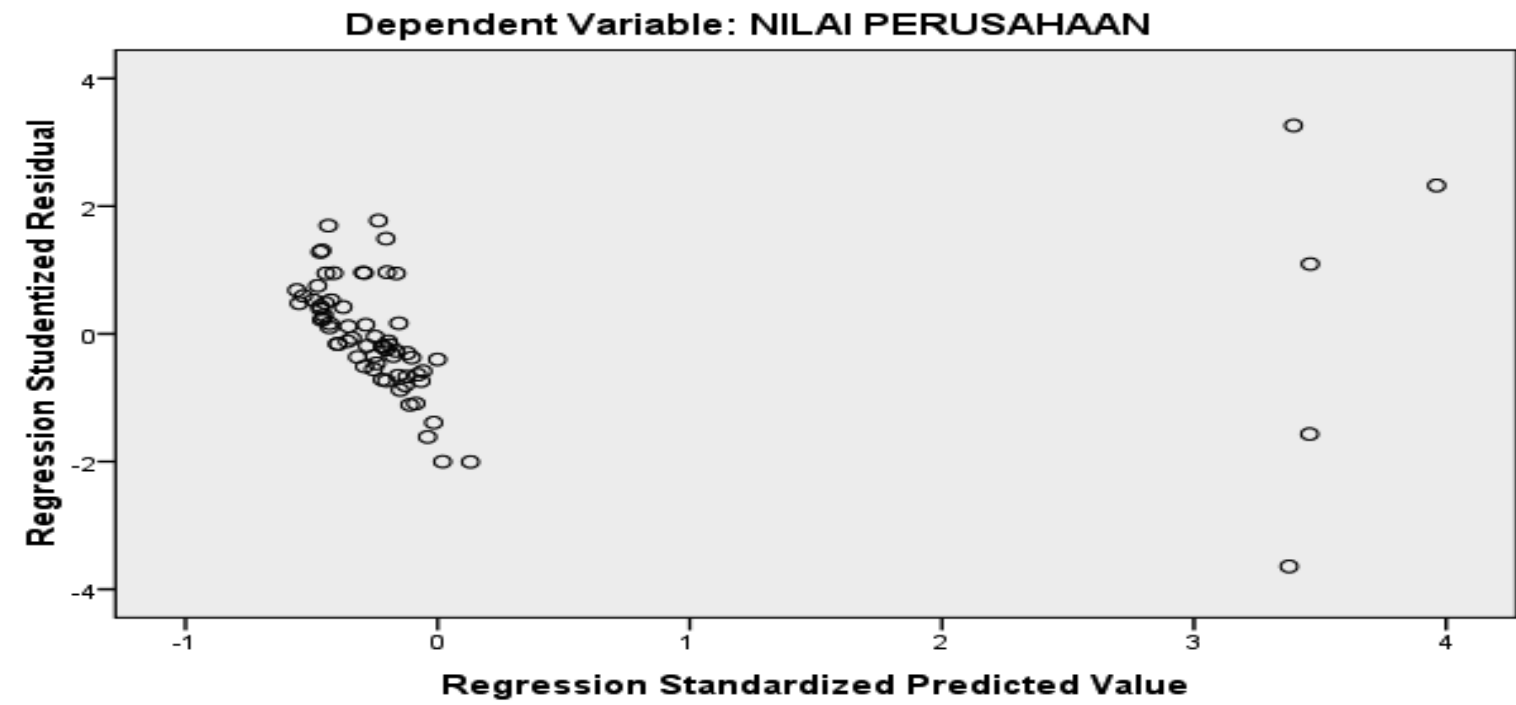

Gambar 1 Uji Heterokedastisitas

Berdasarkan Gambar 1 diatas dapat dilihat angka 0 pada sumbu Y maka dapat disimpulkan bahwa hasil gambar tidak membentuk pola yang bahwa tidak terjadinya heterokedastisitas. jelas serta titik-titik menyebar diatas dan dibawah

Tabel 4 Uji Autokorelasi Sebelum Transpormasi Model Summary ${ }^{\mathrm{b}}$

\begin{tabular}{|l|r|r|r|r|r|}
\hline Model & \multicolumn{1}{|c|}{$\mathrm{R}$} & R Square & \multicolumn{1}{c|}{$\begin{array}{c}\text { Adjusted R } \\
\text { Square }\end{array}$} & $\begin{array}{r}\text { Std. Error of } \\
\text { the Estimate }\end{array}$ & \multicolumn{1}{c|}{ Durbin-Watson } \\
\hline 1 & $.976^{\mathrm{a}}$ & .952 & .950 & 2.906347 & .729 \\
\hline
\end{tabular}

a. Predictors: (Constant), PROFITABILITAS, CSR

b. Dependent Variable: NILAI PERUSAHAAN

Sumber : data yang diolah SPSS 16, 2018

Berdasarkan tabel 4 diatas terdapat gelaja autokorelasi positif dimana $0<0,729<1,5542$ atau $0<\mathrm{d}$ hitung $<\mathrm{dl}$. Akan tetapi setelah dilakukan transformasi data menggunakan Lag nilai Durbin Watson berubah seperti pada tabel berikut: 
Tabel 5 Uji Autokorelasi Setelah Transformasi Model Summary ${ }^{\mathrm{b}}$

\begin{tabular}{|l|r|r|r|r|r|}
\hline Model & \multicolumn{1}{|c|}{$\mathrm{R}$} & $\mathrm{R}$ Square & $\begin{array}{c}\text { Adjusted R } \\
\text { Square }\end{array}$ & $\begin{array}{c}\text { Std. Error of the } \\
\text { Estimate }\end{array}$ & Durbin-Watson \\
\hline 1 & $.870^{\mathrm{a}}$ & .756 & .749 & 6.585973 & 1.883 \\
\hline
\end{tabular}

a. Predictors: (Constant), LAG_X2, CSR

\section{b. Dependent Variable: NILAI PERUSAHAAN}

Sumber : data yang di olah SPSS 16, 2018

Berdasarkan tabel 5 dapat dilihat bahwa nilai du $<$ dhitung $<4$-du atau 1,6697 < 1,883 <2,3285 dengan $\alpha=5 \%$ maka dari itu dapat disimpulkan bahwa tidak terdapat gejala autokorelasi.

dimana du dan dl dapat dilihat pada tabel $d w$

Hasil Analisis Regresi Berganda

Tabel 6 Analisis Regresi Berganda

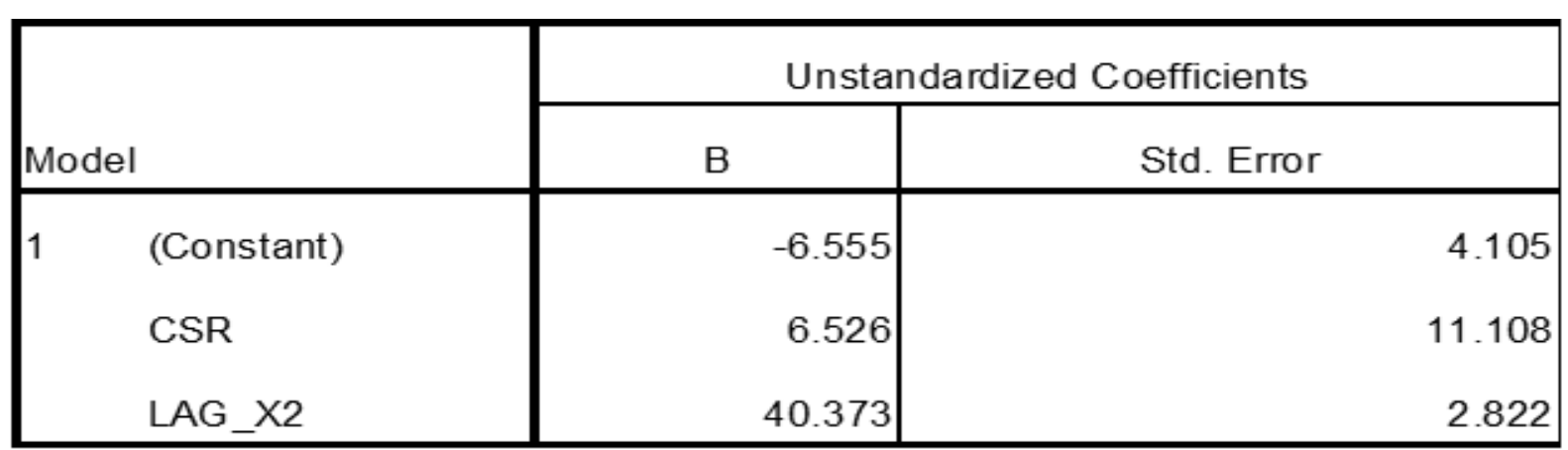

a. Dependent Variable: NILAI PERUSAHAAN

Sumber : data yang diolah SPSS 16, 2018

Berdasarkan hasil pengolahan diatas dapat diperoleh persamaan regresi linier berganda sebagai berikut:

$Y=-6,555+6,526 X_{1}+40,373 X_{2}+e$

Keterangan :

$\mathrm{Y}=$ Nilai Perusahaan

$\mathrm{X}_{1}=\mathrm{CSR}$

$\mathrm{X}_{2}=$ Profitabilitas

Dari persamaan regresi diatas, maka dapat dianalisis sebagai berikut:

30 || Syofria Meidona, Mely Angraini
1. Konstanta yang menunjukkan bahwa apabila nilai CSR dan Profitabilitas adalah 0 atau konstan maka nilai perusahaan akan mengalami perubahan sebesar - 6,555.

2. $\mathrm{X}_{1}$ yang merupakan koefisien CSR bernilai positif sebesar 6,526 yang menyatakan bahwa jika $\mathrm{X}_{2}$ dianggap 0 atau konstan maka setiap penambahan 1 CSR akan menambah nilai perusahaan sebesar 6,526\%. 
3. $\mathrm{X}_{2}$ yang merupakan koefisien Profitabilitas yang bernilai positif sebesar 40,373 yang menyatakan bahwa jika $\mathrm{X}_{1}$ dianggap 0 atau konstan maka setiap penambahan 1 ROE

akan menambah nilai perusahaan sebesar $40,373 \%$.

\section{Hasil Uji Hipotesis}

Tabel 7 Hasil Pengujian Hipotesis Secara Parsial (Uji t)

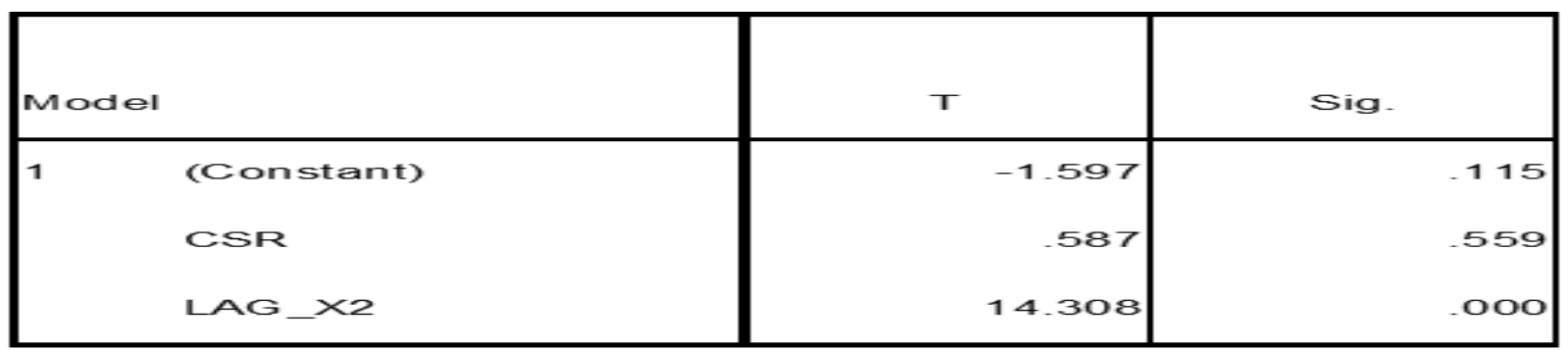

Sumber : data yang diolah SPSS 16, 2018

Berdasarkan tabel 7 dapat diketahui bahwa variabel Pengungkapan Corporate Social Responsibility (CSR) memperoleh hasil signifikan sebesar 0,559 atau 0,559>0,05 serta jika dilihat berdasarkan $\mathrm{t}$ tabel dan $\mathrm{t}$ hitung menghasilkan $\mathrm{t}_{\text {hitung }}<\mathrm{t}$ tabel sebesar 0,587 $<1,668$. maka dari itu dapat disimpulkan bahwa hipotesis pertama yang diajukan di tolak atau variabel Pengungkapan Corporate Social Responsibility (CSR) tidak berpengaruh signifikan terhadap nilai perusahaan dimana hal ini sejalan dengan penelitian yang dilakukan oleh Retno dan Denies yang berjudul pengaruh Good Corporate Governance dan pengungkapan Corporate Social Responsibility (CSR) terhadap nilai perusahaan yang menemukan bahwa CSR tidak berpengaruh signifikan terhadap nilai perusahaan. Akan tetapi penelitian ini tidak sejalan dengan penelitian yang dilakukan oleh Silvia Agustin yang berjudul Pengaruh Pengungkapan Corporate Social Responsibility dan Profitabilitas terhadap nilai perusahaan yang menemukan CSR berpengaruh signifikan positif terhadap nilai perusahaan.

Pengaruh Profitabilitas Terhadap Nilai Perusahaan berdasarkan tabel diatas dapat dilihat bahwa variabel Profitabilitas memperoleh hasil signifikan sebesar 0,000 yang berarti 0,000 $<0,05$ dan jika dilihat berdasarkan $\mathrm{t}$ tabel dan $\mathrm{t}$ hitung menghasilkan thitung > t tabel atau 14,308 $>$ 1,668 maka dari itu dapat disimpulakan bahwa Profitabilitas berpengaruh signifikan terhadap nilai perusahaan yang berarti juga hipotesis kedua yang diajukan dalam penelitian ini di terima. Hal tersebut sejalan dengan penelitian yang dilakukan oleh Suwardika dan I Ketut yang berjudul Leverge, Ukuran Perusahaan, Pertumbuhan Perusahaan dan Profitabilitas terhadap nilai perusahaan yang menemukan Profitabilitas berpengaruh signifikan terhadap nilai perusahaan serta sejalan juga dengan penelitian yang dilakukan Agustina (2013) yang menemukan Profitabilitas berpengaruh signifikan positif terhadap nilai perusahaan. 
ANOVA $^{\text {b }}$

\begin{tabular}{|ll|l|l|}
\hline Model & & F & Sig. \\
\hline 1 & Regression & 102.386 & $.000^{\mathrm{a}}$ \\
\hline & Residual & & \\
\hline
\end{tabular}

Sumber : data yang diolah SPSS 16, 2018

Hasil tabel 8 diatas memperoleh $\mathrm{f}_{\text {hitung }}$ sebesar Corporate Social Responsibility (CSR) dan 102,386 dan jika dibandingkan dengan $\mathrm{f}$ tabel Profitabilitas secara simultan atau bersamasebesar 3,136 dimana artinya adalah $\mathrm{f}_{\text {hitung }}>\mathrm{f}$ sama berpengaruh signifikan terhadap nilai tabel dengan signifikan sebesar $0,000<0,05$ perusahaan.

maka dapat disimpulkan bahwa Pengungkapan

Tabel 9 Hasil Uji Koefisien Determinasi (Uji R ${ }^{2}$ )

Model Summary

\begin{tabular}{|l|r|r|r|r|r|}
\hline Model & \multicolumn{1}{|c|}{$\mathrm{R}$} & R Square & Adjusted R Square & $\begin{array}{c}\text { Std. Error of the } \\
\text { Estimate }\end{array}$ & Durbin-Watson \\
\hline 1 & $.870^{\mathrm{a}}$ & .756 & .749 & 6.585973 & 1.883 \\
\hline
\end{tabular}

a. Predictors: (Constant), LAG_X2, CSR

\section{b. Dependent Variable: NILAI PERUSAHAAN}

Sumber : data yang diolah SPSS 16, 2018

Berdasarkan tabel 9 dapat dilihat bahwa nilai adjusted $\mathrm{R}$ Square sebesar 0,749 maka dapat disimpulkan bahwa 74,9\% variabel nilai perusahaan dijelaskan oleh variabel Pengungkapan Corporate Social Responsibility dan Profitabilitas sedangkan 25,1\% sisanya dijelaskan oleh faktor lain diluar variabel dalam penelitian ini.

\section{PENUTUP}

Berdasarkan hasil penelitian dan pengujian hipotesis dapat disimpulkan bahwa Variabel $\mathrm{X}_{1}$ yang diwakili dengan Corporate Social

32| Syofria Meidona, Mely Angraini
Responsibility tidak berpengaruh signifikan terhadap nilai perusahaan hal ini dapat dilihat pada uji hipotesis yaitu uji t dimana mendapatkan hasil signifikansi sebesar 0,559 atau 0,559 > 0,05 serta jika dilihat berdasarkan $t$ tabel dan $t$ hitung menghasilkan $t_{\text {hitung }}<\mathrm{t}$ tabel sebesar 0,587 $<1,668$.

Variabel $\mathrm{X}_{2}$ yang diwakili dengan Profitabilitas berpengaruh signifikan terhadap nilai perusahaan hal ini dapat dilihat pada uji f atau uji secara simultan mendapatkan hasil signifikansi sebesar 0,000 yang berarti $0,000<0,05$ dan jika dilihat berdasarkan $t$ tabel dan $t$ hitung menghasilkan $t_{\text {hitung }}>\mathrm{t}$ tabel atau 14,308 > 1,668. 
Sementara variabel $\mathrm{X}_{1}$ dan $\mathrm{X}_{2}$ berpengaruh signifikan terhadap nilai perusahaan hal ini dapat dilihat pada uji $\mathrm{F}$ atau uji secara simultan dimana mendapatkan hasil $\mathrm{f}_{\text {hitung }}$ sebesar 102,386 dan jika dibandingkan dengan $\mathrm{f}$ tabel sebesar 3,136 dimana artinya adalah $\mathrm{f}_{\text {hitung }}>\mathrm{f}$ tabel dengan signifikan sebesar $0,000<0,05$.

Beberapa keterbatasan yang terdapat dalam penelitian ini antara lain sebagai berikut:

1. Sampel dalam penelitian ini masih terbatas yaitu sebanyak 14 perusahaan dari 51 perusahaan yang terdaftar di IDX30 periode 2012-2016.

2. Dalam penelitian ini hanya menggunakan periode lima tahun terakhir yang mungkin belum menunjukkan hasil yang sebenarnya untuk variabel Corporate Social Responsibility, dimana belum menunjukkan manfaat yang diharapkan terhadap nilai perusahaan.

3. Dalam menentukan item pengungkapan CSR tidakada ketentuan yang dapat menyeragamkan pemelihan item pengungkapan CSR sehingga pemilihan item pengungkapan CSR akan berbeda untuk setiap peneliti.

4. Media yang digunakan untuk menganalisis item pengungkapan CSR terbatas hanya pada laporan tahunan saja.

\section{DAFTAR KEPUSTAKAAN}

Agustina, Silvia. 2013. Pengaruh Profitabilitas dan pengungkapan Corporate Social Responsibility terhadap Nilai Perusahaan. Skripsi. Universitas Negeri Padang.

Analisa, Yangs. 2011. Pengaruh Ukuran Perusahaan, Leverage, Profitabilitas dan
Kebijakan Devidend terhadap Nilai Perusahaan . Universitas Diponegoro.

Deriyarso, Irvan. 2014. Pengaruh Profitabilitas terhadap Nilai Perusahaan dengan Corporate Social Responsibiliy sebagai Variabel Moderating. Skripsi. Universitas Diponegoro, Semarang.

Dewi, Ayu Sri Mahatma dan Ary Wirajaya. 2013. Pengaruh Struktur Modal, Profitabilitas dan ukuran perusahaan terhadap Nilai Perusahaan. E- Jurnal Akuntansi Udayana, volume 4 nomor 2.

Permanasari, Wien Ika. 2010. Pengaruh Manajemen, Kepemilikan Institusional dan CSR terhadap Nilai perusahaan. Skripsi Akuntansi. Universitas Diponegoro.

Rubiyani, Debi. 2016. Pengaruh Profitabilitas terhadap Firm Value daengan Capital Structure sebagai Variabel Intervening . Jurnal Ilmu dan Riset Manajemen Volume 5 Nomor 1.

Retno, Dyah Reny. 2012. Pengaruh Good Corporate Governance dan Pengungkapan Corporate Social Responsibility terhadap Nilai perusahaan. Jurnal Nominal Volume 1 Nomor 1.

Sugiarto, Yolanda. 2016. Analisis Pengaruh Corporate Social Responsibility dan Good Corporate Governance terhadap Nilai Perusahaan. Skripsi. Universitas hasanudin, Makasar.

Suardika, I Nyoman Agus dan I Ketut Mustanda. 2017. Pengaruh Leverage, Ukuran Perusahaan, Pertumbuhan Perusahaan dan Profitabilitas terhadap NIlai Perusahaan pada Perusahaan Properti. E- Jurnal Manajemen Unud Volume 6 Nomor 3. 
JURNAL IMARA

Mayogi, Dien Gusti dan Fidiana. 2016. Pengaruh Profitabilitas, Kebijakan Deviden dan Kebijakan Utang Terhadap Nilai Perusahaan. Jurnal Ilmu dan Riset Akuntansi Volume 5 Nomor 1.

Nofrita. 2013. Pengaruh Profitabilitas terhadap Nilai Perusahaan dengan Kebijakan Dividend sebagai Variabel Intervening. Artikel penelitian .
Rahmi, Fahla Amalina. 2014. Pengaruh Profitabilitas dan Struktur Modal Terhadap Nilai Perusahaan. Skripsi. Universitas Widyatama, bandung. 